\title{
Recent Developments in Gene Chemistry
}

\section{Bhadury PS*}

$R \& D$ Unit Northernchem Inc. Thorold Stone Road, Niagara Falls Ontario, Canada

*Corresponding author: Bhadury PS. R \& D Unit, Northernchem Inc.4,5,6,7-5743 Thorold Stone Road, Niagara Falls Ontario-L2J 1A1 Canada, Tel: 289-2714323; Email: pinakibhadury@northerncheminc.com

Rec Date: November 03, 2014; Acc date: November 03, 2014; Pub date: November 05, 2014

Copyright: ( 2014 Bhadury PS. This is an open-access article distributed under the terms of the Creative Commons Attribution License, which permits unrestricted use, distribution, and reproduction in any medium, provided the original author and source are credited.

\section{Introduction}

The recent adavancement in the field of nucleic acid, nucleotide, and nucleoside has revolutionized modern day biological and chemical research. The knowledge of synthetic chemistry is essential to prepare modified nucleic acids as potent therapeutic agents and as tools for molecular biology. On the other hand with the help of combinatorial chemistry nucleic acid/peptide libraries are generated and then specific members are enriched and mutated to obtain the most promising chiral catalyst for achieving the desired asymmetric transformations which include regio- and stereoselective transformations of achiral precursors in typical carbon-carbon bond forming and DNAphosphorylation reactions.

As a matter of fact, chemical science plays a major role in enhancing our understanding of nucleic acid and enzyme structures/function and their exploitation for diagnostic and therapeutic applications. Modifications of DNA and enzymology often aid in DNA damage repair. The new technology in gene chemistry would be beneficial to practicing synthetic chemists, biologists, biotechnologists and medical professionals. The growing need for novel synthetic methodologies in this area should never be underestimated. 